\title{
RÁDIOS COMUNITÁRIAS: ESTRATÉGIAS DE MOVIMENTOS SOCIAIS E MODELOS DE AÇÃO DE POLÍTICOS $^{1}$
}

\section{Monique Florencio de Aguiar ${ }^{2}$}

\begin{abstract}
Resumo
Os estudos habituais sobre rádios comunitárias se baseiam em compreensões idealistas que separam grupos dominantes e dominados. A partir daí, associamse aos grupos conceitos polares dotados de julgamentos de valor. Neste artigo, 0 objetivo é evidenciar esta fraqueza e trazer um exemplo etnográfico que torna mais fácil a tarefa de romper com concepções dualistas vigentes nos estudos.

Palavras-chave: Rádios comunitárias. Movimentos Sociais. Políticos. Tipologias.
\end{abstract}

\begin{abstract}
Studies on community radio stations are usually based on idealistic notions that separate groups into dominating and dominated. As a consequence, these groups are frequently associated with polar concepts laden with value judgments. The

\footnotetext{
${ }^{1}$ Agradeço imensamente ao Prof. Dr. Marcelo Carvalho Rosa (PPGSD/UFF) pela orientação que resultou neste texto e pela leitura e correção de expressões. Assim como ao Prof. Dr. Jair de Souza Ramos (PPGA/UFF) pela leitura, sugestões e críticas. As imprecisões ou falhas do texto são de minha responsabilidade.

${ }^{2}$ Mestranda do Programa de Pós Graduação em Antropologia da Universidade Federal Fluminense, monique_aguiar@yahoo.com.br
} 
purpose of this article is to make this weakness clear, and provide an ethnographic example that facilitates the task of breaking with the dualistic conceptions characteristic of most studies.

Keywords: Community Radio Stations. Social Movements. Politicians. Typologies.

\section{INTRODUÇÃO}

$\mathrm{E}$ ste texto aborda a compreensão sobre rádios comunitárias vigente rotineiramente na literatura que cobre o fenômeno. Essa compreensão é influenciada por teorias marxistas e gramscianas que vão da ênfase nas bases materiais à ênfase nas bases imateriais em direção a uma mudança social revolucionária. Contudo, desvelando o teor não revolucionário do surgimento e trajetória das rádios comunitárias, pretendi romper com dicotomias entre "público" e "privado" e conceitos de valor que separam movimentos sociais e políticos. Aqui, examino concepções que são meramente ideais da utilização das rádios comunitárias.

Assim, o uso de termos como clientelismo e assistencialismo é compreendido de forma mais neutra e, num segundo momento, por meio de um exemplo, vemos mais claramente a crítica da aplicabilidade de categorias duais utilizadas nos estudos sobre rádios comunitárias. Tais estudos terminam por aderir às reflexões militantistas.

\section{Uma Crítica ao Perfil da Literatura sobre RÁdios Comunitárias}

A investigação que ganhou corpo neste trabalho teve como ponto de partida um interesse peculiar de observação sobre as práticas políticas envolvidas na utilização de uma rádio comunitária. Compreendendo, já de início, o espaço da comunicação como uma esfera de poder ${ }^{3}$, empreendi, principalmente, a leitura

\footnotetext{
${ }^{3}$ A compreensão do espaço da comunicação como uma esfera de poder reside no entendimento sobre a produção de sentido que busca convencer o interlocutor, criando um espaço de disputas de argumentação. Mais especificamente, no caso das rádios comunitárias, evidencia-se a ênfase "de sua participação no processo de organização e mobilização dos segmentos sociais subalternizados" (COSTA JÚNIOR,1999, p.12), desempenhando uma função junto aos novos movimentos sociais que formavam vínculos com a comunidade e redes de comunicação.
} 
de teses, pois aproveitavam como base uma literatura maior. Além das teses, travei contato com alguns artigos.

$\mathrm{Na}$ literatura à que tive acesso, excluindo, imediatamente, os estudos de cunho eminentemente teórico, nota-se o insistente modo de pensar a realidade social sob o dualismo dominantes/dominados. Nogueira (2005, p.209), em sua etnografia sobre as emissoras de rádio de Ilhéus, também ressaltou a existência da compreensão dualista do fenômeno, a qual julgou ser "uma camisa de força", que já vem sendo ultrapassada por autores como "Sánchez-jankowski, 1994; Ortiz, 1989; Gitlin, 1980; Martin-Barbero, 1987". De outro lado, os autores examinados a fim de ampliar meu conhecimento sobre as rádios comunitárias, como, por exemplo, Bianco (1991), Costa (1997), Mello (1999), Luz (2001), Teixeira (2004), Santos (2004) e Nunes (2004), apresentam os grupos, em determinados aspectos, como coesos em conformidade com uma compreensão marxista, e mesmo que assim não se auto-intitulem, herdam, inclusive, a perspectiva um tanto profética. Avançam, logicamente, em abarcar algo que tem como intuito mudar a "ideologia dominante", ou seja, penetram no universo da dita "superestrutura" acreditando no seu potencial para transformar as relações entre as "classes sociais" 5 . Diferentemente, Marx acreditava que a transformação deveria começar pela posse das bases materiais sob poder da "classe revolucionária", pois concluía que o pensamento dominante de uma época era consequiência do poder material dominante (MARX E ENGELS, 2002, p.48). Assim, Marx julgava olhar além das aparências e previa que a experiência de luta conjunta dos operários, como classe revolucionária, tendo como preocupação imediata os salários levaria a uma "real consciência" dos elementos envolvidos na luta de classes (IANNI, 1982, p.29). Desse modo, percebe-se que os autores estudiosos das rádios comunitárias rompem com esse pensamento ao não ressaltarem o poder de transformação que

\footnotetext{
${ }^{4}$ Superestrutura remete à produção de idéias e de representações que para Marx emana da atividade material e do comércio material dos homens. A produção intelectual, pertencente à esfera da superestrutura, apresenta-se na "linguagem da política, na das leis, da moral, da religião, da metafísica, etc” (MARX E ENGELS, 2002, p. 18).

${ }^{5}$ Em 018 Brumário de Luís Bonaparte (1978), Marx percebe as classes sociais não apenas como um bloco monolítico, mas contendo frações ou facções de classe com interesses muitas vezes distintos, embora possuindo a classe proprietária dos meios de produção maior capacidade de efetuar negociações entre os interesses de facções. Já Guiddens (1991, p. 154,161-162), contrariando Marx que concebia a classe proletária como revolucionária, chega atualmente a mencionar que a mudança é passível de ocorrer pela própria classe privilegiada, por possuir os recursos necessários e justamente por nutrir interesses divergentes.
} 
parte, preponderantemente, de bases materiais ou concretas; ao contrário disso, esses autores valorizam a estratégia discursiva, tendo como finalidade desencadear mudanças sociais, estimando, portanto, o potencial das forças imateriais.

Pelo menos desde as inovações do interacionismo simbólico, vemos que as representações são capazes de produzir "realidade". Merton (1970) mencionou isso em "A Profecia que se Cumpre por si Mesma", enquanto Bourdieu (1989), mais próximo de nosso tempo, mencionou também em "A Identidade e a Representação". Anteriormente, a cultura, em seu simbolismo, foi relegada a um segundo plano diante da "materialidade". E hoje ainda atualizamos a perspectiva materialista, relegando 0 aspecto imaterial.

Assim, muitos estudos que aderem a esse esquema - de transformação pelas forças imateriais - utilizam uma perspectiva gramsciana ${ }^{6}$ pautada pelo conceito de hegemonia e deslizam em direção a uma idealização das rádios comunitárias, como força contra-hegemônica. Nos estudos, as práticas desenvolvidas no âmbito das rádios comunitárias passam a ser encaixadas dentro de certos conceitos julgados positivos, e tais rádios são vistas, sempre apesar dos pesares - pois a realidade observada nunca se encaixa ao modelo -, como as "salvadoras do mundo". Diante de tal postulado, cabe aos pesquisadores verificarem o que está certo, ou seja, enquadrado ao modelo, ou o que está errado.

A idealização das rádios comunitárias caminha pari passu com a idealização dos movimentos sociais. Para a maioria dos autores examinados, as rádios comunitárias surgem dentro dos movimentos sociais, dando vozaos excluídos impossibilitados de se expressarem nos meios de comunicação monopolizados. A rádio comunitária, assim, vinha a ser entendida como um instrumento para transformação da sociedade. Contudo, similarmente, temos na literatura sobre os movimentos sociais uma grande herança do pensamento marxista, sobre a qual se baseiam idéias pautadas na concepção de uma mudança rumo ao socialismo. Em

\footnotetext{
${ }^{6}$ Para Gramsci, a classe em sua luta pela hegemonia cultural e política teria a tarefa de criar seus próprios intelectuais organicamente, além de lutar pela assimilação dos valores progressistas transmitidos pela camada dos intelectuais tradicionais. Essa nova intelectualidade quebraria 0 monopólio da direção cultural (legada à igreja católica) e nasceriam com as primeiras células econômicas sob a base industrial. Os intelectuais orgânicos, provenientes do grupo no qual nasceram, formam uma classe heterogênea (pois as particularidades individuais mais profundas não são extinguíveis) e caberia ao intelectual homogeneizar a classe trabalhadora e elevá-la a consciência de sua própria função histórica (transformar uma classe "em-si" numa classe "parasi" (GRAMSCI, 1991).
} 
termos de ilustração, podemos indicar autores como Hobsbawm (1970) e Castells (1980). Hobsbawme Castells se assemelham quando valorizam a urbanização como um desenvolvimento das "forças produtivas" para concretização das mudanças anticapitalistas. Entretanto, como o momento histórico ao qual se refere Hobsbawm é outro, ele ainda contempla a "classe operária" como grande agente de mudança, enquanto Castells vem se adaptar às circunstâncias produzidas socialmente ao longo do tempo, compreendendo as massas sociais de forma mais ampla como agentes em bloco na construção de uma alternativa socialista. Segundo Castells, o sistema mudaria progressivamente pela democratização, chegando à extinção das classes e, portanto, ao fim da exploração. Com essa demonstração do princípio de tais teorias sobre os movimentos sociais, encerram-se os exemplos da vertente revolucionária dessa literatura e, tendo as rádios comunitárias se desenvolvido em boa parte de sua trajetória como um instrumento dentro dos movimentos sociais, não poderiam elas deixar de se impregnarem por tais ideologias.

\section{Rádios Comunitárias no Brasil: as “AUTÊNTICAS”}

Segundo Costa Júnior (1999, p.108), as rádios comunitárias surgiram no Brasil, na década de 60 , por iniciativa de jovens estudantes de eletrônica "motivados muito mais pela curiosidade e satisfação pessoal, do que pela vontade de mudar os rumos políticos do país". Desse modo, descarta-se a versão da origem das rádios comunitárias brasileiras a partir de um movimento revolucionário. Notavelmente, tratava-se de um repúdio à programação das emissoras oficiais por intitulados rádio-amantes, apreciadores de músicas que não gozavam de espaço nas emissoras comerciais existentes. Contudo, essa prática, à época, configurava crime contra a segurança nacional, tendo sido tais experiências combatidas e punidas pelos aparatos repressivos do governo. Sob esse ponto de vista, a atitude de inaugurar seu próprio sinal de rádio era uma ousadia porque possibilitava romper com o monopólio da fala.

Ademais, ainda segundo Costa Júnior (1999), na década de 70 novos movimentos sociais se empenharam em buscar legitimidade através de espaços na mídia. No entanto, como o acesso aos meios oficiais de comunicação era restrito, a solução foi adotar meios alternativos, como jornais mimeografados, panfletos e sistemas de alto-falantes. Assim, posteriormente, tais movimentos sociais descobriram no rádio uma ferramenta para difusão de suas pretensões e atividades, evidenciando a imagem desse meio de comunicação como veículo de resistência e inclusão social em oposição às rádios oficiais (comerciais ou governamentais). 
Alguns estudos abordam determinados lugares-comuns a respeito da utilização que sempre ocorreu das rádios legais por governantes com propósito de aumentar sua legitimidade. No surgimento desse veículo no Brasil, em 1922, a primeira emissão foi o discurso do presidente Epitácio Pessoa (PASSINI, 2005, p.22). Posteriormente, os demais presidentes também se valeram desse veículo de massa para propagarem suas idéias políticas (PASSINI, 2005, p. 21-31). Nesse fenômeno, não há nada de misterioso, como querem fazer crer alguns autores, pois salta aos olhos o fato de uma figura que se expõe num veículo de massa gozar de maior notoriedade, o que se alia aos interesses de políticos que primam por números de votos. Tão pouco, trata-se de uma peculiaridade brasileira visto os exemplos de políticos que usaram a mesma estratégia pelo mundo: Roosevelt, Hitler, Mussolini, Juan Domingo Perón etc. Destarte, a posse do monopólio da fala fornece a capacidade de aumentar o poder do seu possuidor e tem se revelado, como mencionou Miguel (2003, p. 117), um ótimo instrumento para eleger outsiders. Assim como os estudos que abordam a propensão de ganhar maior apoio político e visibilidade usando o rádio como instrumento, há diversos estudos contemplando o poder de mediação exercido pelos locutores.

Bianco (1991), em seu estudo intitulado Rádio Populista, clarifica aspectos sobre a mediação do rádio nas relações entre as classes populares e o Estado. Partindo da análise de dois programas transmitidos em frequiência AM, a autora desvendou estratégias dos locutores para colocar em pauta os processos reivindicatórios. Nessa relação, o Estado utiliza o programa como estratégia de aproximação das classes populares; os moradores, por sua vez, dão publicidade às suas demandas e pressionam o Estado a respondê-los "sob pena de perder a legitimidade conferida por eles através do voto" (1991, p.185). Além disso, os locutores aproveitam essa relação, ostentando a prestação de serviço à comunidade, para disputarem cargos eletivos servindo-se do espaço radiofônico para campanha eleitoral. Desse modo, os locutores encarnam o papel de representantes do povo junto ao poder, o qual se torna dependente dos líderes identificados com a sua causa e, na medida em que tais líderes possuem acesso direto ao governo, ganham legitimidade por parte do povo. Portanto, para Bianco (1991), esta relação descambava para o clientelismo e para personalização, assumindo os locutores a posição de porta-vozes fiéis e solidários às carências. Nos estudos, como os de Passini (2005) e Bianco (1991), que se referem ao fenômeno da mediação realizada pelos locutores, termos como "assistencialismo" e "clientelismo" são demasiadamente utilizados e mais adiante questionaremos tais usos valorados. 
Diante do monopólio dos meios de comunicação, desencadeado pela prática do governo federal de ceder concessões aos amigos e parceiros políticos em troca de favores, enfatizou-se o novo objetivo secundário de alguns movimentos sociais, que passou a ser reivindicar a democratização do espaço eletromagnético. Desse modo, os movimentos sociais buscavam solucionar uma necessidade de comunicação fora do institucional, empreendendo a irradiação dos seus discursos. Para que isso se realizasse sem a sombra da repressão governamental exercida por meio de prisões e apreensão de equipamentos pela polícia federal, os movimentos começaram a buscar uma legitimação dessa conquista via regulamentação de uma política de concessões mais democrática (COSTA JÚNIOR, 1999).

Gradualmente, a iniciativa pela democratização dos meios de comunicação foi se organizando. Desde a 'Cooperativa dos Rádio-Amantes', que visava, entre outras coisas, socializar informações técnicas e prestar ajuda e solidariedade a qualquer grupo de rádio-amantes, temos iniciativas mais recentes como a ABRAÇO (Associação Brasileira de Rádios e Televisões Comunitárias), fundada em 1996, que possui associações estaduais como suas filiadas e vincula-se, sobretudo, à Associação Mundial de Rádios Comunitárias (AMARC), fundada no Brasil em 2001. Com as pressões do movimento ganhando ampla dimensão, a lei que regulamenta as rádios comunitárias foi emitida em 1998 (TEIXEIRA, 2004).

Dessa forma, as rádios comunitárias, a partir da luta pela legalização, buscaram a aproximação e a proteção do Estado. Este, por sua vez, por meio da estipulação de regras de uso das rádios, via a possibilidade de um maior controle sobre elas. Para Costa Júnior (1999, p.109), o maior motivo para aceitação do funcionamento das rádios comunitárias se deve à descoberta por parte dos políticos de que tais rádios poderiam ter uma utilidade eleitoral se usadas pelas entidades apoiadoras. Com o projeto de lei tramitando no Congresso, vários deputados, prefeitos e líderes políticos aproveitavam para montar a sua emissora (ibidem, p.111).

Após a exposição realizada acima, sobre o surgimento das rádios comunitárias e sua trajetória, torna-se evidente o esforço em direção à legalização, configurando uma tentativa de aproximação do Estado para legitimar as práticas do movimento. Verificamos haver uma negociação entre o movimento social e o Estado em consonância com a teoria de Boschi (1987), o qual afirmou que os movimentos precisam de uma mediação institucional para poder agir, não conseguindo cortar relações com as instituições democráticas e liberais e, 
portanto, não se eximindo da assistência do Estado. Para Boschi, o movimento não tem como romper com a ordem anterior, como preconizam alguns teóricos que constantemente atualizam a teoria marxista ${ }^{7}$, porque ele é fruto dessa ordem. Desse modo, predominam perspectivas de promover uma mudança social não direcionada a fins revolucionários. De acordo com o que vemos na trajetória das rádios comunitárias, trata-se de uma luta pelo reconhecimento de um direito que inclui as minorias no "sistema atual", alterando esse sistema minimamente no sentido de absorver essas parcelas excluídas. Essa assertiva, que pode ser vista como conservadora, vai ao encontro da teoria de Honneth (2003) sobre os movimentos sociais.

Partindo da legalização das rádios comunitárias que se incorporam ao "sistema", muitos autores postularam um desvirtuamento em termos dos fins das rádios comunitárias. Isso aconteceria pela apropriação da idéia de montagem das rádios por políticos locais. Nessa perspectiva, os representantes de movimentos sociais desejam manter o monopólio dessa idéia acusando os políticos de usurparem e modificarem algo que lhes pertenciam, demonstrando a luta pelo poder de influência existente nessa relação. Ora, se tais políticos se apropriaram da idéia de utilização das rádios comunitárias para reforçar seu poder local, será que, seguindo a mesma lógica, não deveríamos "acusar" os movimentos sociais de se apropriarem de uma idéia dos rádio-amantes e levarem tal invenção a um embate muito maior de forças, descaracterizando sua origem? 0 que procuro com essa argumentação é mostrar como os estudos sobre rádios comunitárias acabam por ter sua interpretação enviesada por posições puristas. Assim sendo, os dois agentes - políticos e integrantes de movimentos sociais ${ }^{8}$ - desejam com as rádios ser reconhecidos e notados, utilizando esse veículo como instrumento de poder, não importando se quem as utiliza tem maior ou menor poder (o poder dominante, hegemônico).

A grande acusação verbalizada contra as rádios comandadas por políticos é sintetizada em termos tais como doutrinação ou proselitismo. Cabe, portanto, perguntar se o discurso dos movimentos sociais não é doutrinador? A diferença, então, das práticas doutrinadoras dos dois grupos confrontados se dá na distinção do discurso, pois um é de oposição e o outro é, geralmente, de apoio ao poder

\footnotetext{
${ }^{7}$ A esse respeito, ver. Alexander (1998), o qual discute a secularização, inversão, atualização e deslocamento das teorias sobre movimentos sociais que se pautam pelo modelo clássico marxista.

${ }^{8}$ Lembrando que dentro dos movimentos sociais há militantes políticos.
}

RÁdIOS COMUNITÁRIAS: ESTRATÉGIAS DE MOVIMENTOS SOCIAIS ... 
estabelecido. A idéia de mudança revolucionária é sobrevalorizada por muitos indivíduos, compondo, na maioria das vezes, uma polarização entre conservadores (julgados negativamente) e revolucionários (julgados positivamente). Nada tenho contra tal entendimento, porém no momento em que essa categorização evade para o campo dos estudos sociais, a "realidade" se vê amarrada a conceitos de valor e por demais modificada, quando induzida por essas posições ortodoxas.

Desse modo, confrontamo-nos com um ideal de rádio comunitária versus sua existência "real", o que contribui para que muitos estudem algumas rádios no intuito de verificarem se as características encontradas se encaixam no modelo estipulado de rádio comunitária, profetizando, ainda, como ela deveria ser. Assim, ensina Nunes:

0 que a rádio livre representa para a comunicação social é a geração de novas relações de poder, descentralizado e democratizado. 0 primeiro passo para isso é admitir que o poder é bom, pode libertar e emancipar. (...) Os valores já não serão mais aqueles padronizados pelo mercado oficial de bens culturais e sim aqueles que constroem a identidade da comunidade ou do grupo que organiza o processo, favorecendo a subjetividade e a cidadania (2004, p. 67).

De tal modo, o almejado ideal de rádio comunitária propagado pelos seus defensores é aquele que: valoriza a pluralidade social, amplia a esfera pública local, promove a participação popular, conscientiza politicamente, trabalha a cidadania, presta serviços, democratiza a sociedade, não adere à defesa de candidatos ou partidos políticos, não possui fins lucrativos, incrementa a cultura e a identidade locais etc. Conseqüentemente, lamenta Nunes:

0 grande desafio que se coloca hoje é a regulamentação imediata das experiências autenticamente comunitárias, separando o joio do trigo, para que essas emissoras que representam efetivamente os interesses coletivos tenham condições de sobreviver. [...] A legalização é o primeiro passo numa longa e permanente luta pelo exercício alternativo da cidadania através das emissoras autenticamente comunitárias, que têm de enfrentar a concorrência desleal dos comerciantes e políticos que se escondem atrás do rótulo comunitário para defender seus interesses privados. [grifos meus] (apud TEIXEIRA, 2004, p.138).

\footnotetext{
${ }^{9}$ Noto o questionamento na antropologia em relação ao termo real, pois existem várias versões sobre um mesmo fato, o que não impede que seja real para quem o relata. Portanto, há interpretações. 0 que questiono são as análises científicas muito descoladas de como as pessoas vivem a relação com as rádios comunitárias.
} 
Nunes (2004) tem uma compreensão que expande o entendimento de grupos polarizados coesos, dominantes e dominados, como na vertente marxista da dialética das classes ${ }^{10}$. A partir daí, novas dificuldades surgem. Em seu estudo sobre as rádios comunitárias nas campanhas eleitorais de 1998 e 2000 no estado do Ceará, a autora propõe a tipologia dualista: exercício de cidadania ou instrumentalização. Como visto anteriormente, tanto movimentos sociais quanto políticos com discursos governistas instrumentalizam as rádios, buscando associar as pessoas à causa do seu movimento. Do mesmo modo, o exercício de cidadania (como permissão ao dissenso e à pluralidade) pode ser levado a cabo por ambos, políticos ou movimentos sociais. Assim, a autora, a partir de seu estudo sobre algumas rádios - que compreendia a obtenção do histórico da rádio e a gravação de alguns programas, examinando o discurso -, buscou separar as rádios que realizavam o "exercício de cidadania" e as que "instrumentalizavam" ou manipulavam. A partir daí outras tipologias surgem como: instrumentalização direta, indireta ou subliminar; e a existência de rádios, que segundo a autora, são mistas, ou seja, nem instrumentalizam nem praticam exercício de cidadania completamente. Com isso, estabelece-se um jogo de conceitos enquadradores, os quais confundem ao tentar simplificar.

As emissoras comunitárias mistas, segundo Nunes, seriam aquelas que:

não são totalmente instrumentalizadas pelos políticos, contando com certa participação popular. Algumas emissoras são montadas por políticos e, depois, entregues à comunidade, que passa a gerenciá-las, contando com o apoio do chefe político (NUNES, 2004, p.68).

Ora, existem as instrumentalizadas, as que desenvolvem o exercício de cidadania e as mistas. 0 perigo de se trabalhar com conceitos polarizadores acontece justamente quando encontramos uma configuração que não se adéqua nem a um modelo nem a outro e quando o conceito já não o abarca, criamos outro, porque nos interessamos mais em rotular um fenômeno ${ }^{11}$ do que em compreender seus meandros. Isso em nada constitui o que chamamos de generalização no campo das ciências sociais, pois esta é uma interpretação geral que provém de uma inferência após examinarmos e descrevermos cuidadosamente um fato, sem, contudo, haver necessidade de criar um novo conceito.

\footnotetext{
${ }^{10}$ Para uma pequena crítica da dialética marxista das classes, ver Guiddens (1991, p. 4-15, 55-56, 154-155).

${ }^{11}$ A respeito da rotulação de fenômenos intermediários, ver Douglas (1966, p. 50-55).
} 
Quanto às formas de instrumentalização, Nunes nos oferece as diretas como sendo aquelas nas quais se apresenta a divulgação do nome do candidato na programação, e as indiretas, nas quais não se divulga o nome do candidato, mas se divulgam as suas obras. Além disso, a autora apresentou a forma que julga a mais significativa, a subliminar. E, em relação a esta forma, afirmou que ela:

...não se dá tanto por interesses econômicos e políticos partidários. Ela ocorre, na maior parte das vezes, por desconhecimento do papel das emissoras junto à comunidade. Os locutores e produtores em sua maioria, não tem noção do potencial aglutinador e mobilizador das rádios comunitárias (NUNES, 2004, p.71).

Sendo essa a única informação que temos no texto sobre a forma subliminar de instrumentalização e entendendo que ela não divulga nem o nome nem as obras do candidato, como ela se dá na prática? Isso efetivamente ficamos sem saber. No entanto, quando Nunes descobriu uma rádio que julgou realizar o exercício de cidadania, visto que ela não propagava o nome nem as obras de um candidato, mencionou que:

Apesar de muitos de seus militantes serem ligados a partidos de esquerda, especialmente 0 Partido Comunista do Brasil (PCdoB), em nenhum momento ouviu-se qualquer referência a questões partidárias ou ao candidato do PCdoB à prefeitura de Fortaleza nas eleições de 2000, Inácio Arruda (NUNES, 2004, p.72-73).

Desse modo, o discurso efetuado por essa rádio, por exemplo, sobre a importância do voto e que é julgado conscientizador não se entrelaça à imagem do partido? Sabendo as pessoas da comunidade ou vindo a saber que esta rádio tão "qualificada" era composta por militantes do PCdoB, isso não causaria certa influência sobre a aceitação do partido? Poderia ser uma forma subliminar de instrumentalização? Tais questões ficam no ar e a deficiência desses estudos demonstra 0 interesse apenas em conferir os pareceres das pesquisas. Assim, voltamos ao ideal de rádio comunitária, pois para classificar e efetuar essas tipologias é preciso que as rádios observadas obedeçam a certas regras que as promovam ao título de exercitadoras da cidadania.

Aqui, proponho um novo argumento: praticar o exercício da cidadania não promove interesses privados? No modelo ideal de rádio comunitária, ela deve atender à comunidade e ampliar a esfera pública; agora, é inegável que uma rádio comandada por um político pode obedecer a essas regras e, no entanto, defender seus interesses privados ao mesmo tempo. Dessa forma, ser uma rádio 
"verdadeiramente" comunitária, seguindo as regras, não impede que ela seja instrumentalizada, mesmo que seja pela boa fama que o político ganha por desenvolver a comunidade. Além disso, se, por exemplo, buscarmos definir uma rádio unicamente pela programação, podemos julgá-la como comunitária sem perceber que em seu contexto de ação, em sua entidade gestora, há práticas que comportam interesses privados na medida em que um político procure se promover a partir de um contato pessoal desenvolvido com os ouvintes por conta de projetos na entidade gestora. Assim, o público se emaranha ao privado, dificultando os interesses dos estudiosos que buscam "separar o joio do trigo", pois a realidade não comporta tipos puros.

Vemos políticos que se esforçam em ser instrumentos para a comunidade e, de fato, acabam sendo, mesmo que na próxima eleição os beneficiados se vejam comprometidos em conceder seu voto a esse político. Não obstante, vemos estudos nos quais o maior interesse seria, por exemplo, responder se a rádio pesquisada, em consonância com a hipótese sobre a função da rádio comunitária, amplia ou não a esfera pública. Com isso, o autor se vê sempre mencionando: "apesar de ser assistencialista e promover interesses privados, também podemos dizer que amplia sim a esfera pública." Podemos exemplificar esse comportamento em um trecho da tese de doutorado de Teixeira (2004), no qual podemos constatar o inevitável desencaixe da prática pesquisada em relação aos referenciais teóricos enquadradores, justificando, no entanto, à sua maneira, tal impossibilidade entre 0 ideal e 0 real das rádios comunitárias:

A rádio comunitária de Samambaia mostrou ser mais assistencialista por estar mais voltada a prestar ajuda, principalmente de ordem material a seus ouvintes. (...) A realidade da rádio comunitária de Brazlândia, apesar de ser também assistencialista, tem apresentado mais programas de conscientização. (p. 143). Além disso,pode-se dizer que o estímulo por parte das rádios comunitárias pesquisadas, levou à formação de esferas públicas específicas (...). Em muitas situações percebeu-se uma proximidade a interesses privados, portanto não comuns aos interesses da comunidade. Mesmo diante dessas limitações, os espaços públicos formados ainda assim, refletem em parte, os interesses públicos da localidade. (p. 143) (...) Em certa medida, percebe-se o uso desse tipo de meio de comunicação de uma forma instrumental. (...) somente por meio de suas experiências práticas pode-se dizer com mais certeza se nos aproximamos ou se nos afastamos mais desta utopia'... (TEIXEIRA, 2004, p. 143, 145; grifos meus). 
A propósito, constatamos que dentro de uma mesma ação (como a distribuição de uma cesta básica) podemos encontrar as devidas atribuições: assistencialismo, prestação de serviço ou mesmo prática de solidariedade. Desse modo, os escritores manejam termos que significam a mesma coisa, porém incutem um tom recriminatório ou negativo para uma rádio e positivo para outra. Isso não é questionado, sendo perceptível que é mais fácil nomear como assistencialista uma distribuição de cesta básica por um político do que por um movimento social, já que estamos inevitavelmente presos a estereótipos. 0 cientista, muitas vezes, encontra-se absorvendo essa construção social de termos carregados pelo senso comum de tons positivos ou negativos, e imprimindo essas marcas em seus trabalhos.

\section{A Rádio Comunitária do Largo das Flores em SEU EsPaço SociaL}

ARádio Comunitáriapesquisadaéintitulada Rádio Flores, ou simplesmente 'RF', e tem como instituição sede ou gestora a Associação Comunitária do bairro Largo das Flores, que promove alguns projetos sociais. Por meio desse exemplo etnográfico, lançamos mais luz sobre a inviabilidade de se trabalhar com modelos ideais de rádio comunitária. ${ }^{12}$

Na primeira vez em que me dirigi à associação, com a intenção de conhecê-la, logo percebi quem era o EG0 da figuração que constituía a Associação $\mathrm{RF}$, pois todas as informações me eram passadas por ele, enquanto as outras pessoas encontradas no lugar se eximiam da responsabilidade de me ajudar a respeito da história daquela instituição. Essa figura mor atendia pelo nome de Marcos, autodenominava-se diretor da associação e dividia a direção com mais três personagens, que nos tempos iniciais da rádio participavam mais ativamente. Contudo, com o passar do tempo, percebi que os demais diretores eram verdadeiros "fantasmas" na instituição e, naquele momento, colaboravam para emprestar seus nomes para os fins de legalização da rádio e da entidade gestora. A falta da divisão na direção ficou evidente.

Marcos sempre militou na comunidade, onde cresceu. Foi da associação de moradores local, candidatou-se duas vezes a vereador, não sendo eleito, e uma vez a vice-prefeito, não sendo eleito novamente. Suas candidaturas foram em

${ }^{12}$ Os nomes do lugar, da rádio e das pessoas mencionados nessa sessão são fictícios. 
eleições consecutivas até o ano 2000. Desse modo, chegamos ao ponto no qual se revela algum interesse político na montagem da rádio comunitária. A associação foi formada em 1989 e legalizada em 2001. Três meses após a legalização da instituição, a rádio era posta no ar pela primeira vez, tendo sua licença de funcionamento expedida em fins de 2002.

Enquanto eu remexia algumas pastas contendo documentos sobre a associação e a rádio, encontrei uma Carta Circular, datada de setembro de 2002, convidando as instituições da comunidade para criarem o Conselho Comunitário da rádio, na qual se seguiam diversas assinaturas de representantes de instituições locais. Tal iniciativa demonstra uma tentativa de aumentar a participação da comunidade na rádio, em conformidade com o modelo ideal de rádio comunitária; contudo, desconheço se esse conselho alguma vez se reuniu e porque não se desenvolveu. 0 que pude constatar na época do estudo é que ele não existia. Uma resposta para a inviabilização do conselho pode ser buscada na estratégia do monopólio, a qual vários políticos lançam mão diante da concorrência pelos instrumentos políticos. Prezando pela transparência e participação, atrai pessoas, que se tornam adeptas ou clientes do político. Porém, na medida em que a participação não gere mais clientes, mas sim concorrentes, tal participação é evitada pelo político a fim de manter seu espaço de atuação.

Por outro lado, ficou perceptível que se Marcos muitas vezes procurava direcionar as ações a serem desenvolvidas para se encaixar num modelo ideal de atuação e discurso das rádios comunitárias, os próprios comunicadores e demais integrantes, em contraste com esse direcionamento, não faziam questão de agirem conforme tais modelos de participação e, em alguns momentos, demonstravam nem ao menos saber a importância de tais ênfases para a legitimação de uma rádio comunitária. Desse modo, presenciei o irmão de Marcos, que o ajudava na rádio e havia participado da oficina de rádio (oferecida pela associação), tendo inclusive um programa, criticar junto aos seus colegas a vinheta que dizia: "Esses são os apoiadores culturais da rádio RF...". 0 irmão de Marcos julgava tal frase "muito feia" e disse que ele havia comentado sobre isso com Marcos, mas este tinha insistido no uso dessa frase. 0 irmão de Marcos parecia não compreender que aquela era uma forma de distinguir a rádio comunitária de uma rádio comercial, pois só as comunitárias possuíam apoiadores culturais, enquanto as outras possuíam anunciantes por terem fins lucrativos. 0 irmão de Marcos seguiu dizendo: "se já estão anunciando, quer dizer que estão pagando, não precisa da frase". Verificamos que Marcos, por meio deste exemplo, realiza tentativas de 
aproximação de uma regra que enuncia como devem agir as rádios comunitárias para serem consideradas comunitárias; no entanto, essa prática reflete uma imposição ou artificialização pautada por uma consideração de "cima" do que é correto.

Para Marcos, havia muita importância o fato de mostrar e de fazer da rádio uma rádio comunitária. Alguns leitores dirão que seria em benefício próprio, privado, já que ele era um político interessado nas eleições; outros mencionarão que de fato a rádio era comunitária, pois estava servindo à comunidade e ampliando, assim, a esfera pública. Essa ambigüidade é patente e, em uma das vezes em que fui à associação, encontrei uma menina preenchendo uma ficha de seleção, com 0 intuito de participar de um programa governamental. A menina me perguntou algo sobre a rádio, mas como o Marcos, mais apto a responder, estava perto de nós, eu disse apontando-o: "ele é o dono". Marcos se assustou e disse: "Dono, não, eu ouvi bem?". Assim, um pouco constrangida, respondi: "Ah, sim, diretor, diretor". No entanto, em determinada ocasião, na qual Marcos me contava que foi forçado a deixar um trabalho no CREA $A^{13}$ por tentarem envolvê-lo em um caso de corrupção, lamentei o fato dizendo: "que pena, não é?"; e ele mencionou: "mas se não tivesse acontecido isso, eu não teria tudo isso aqui". 0 que demonstra a convivência ou complementaridade das esferas de interesse público e privado.

Outra barreira para a manutenção do funcionamento da rádio se dava pela quase inexistência de colaboração do comércio local, que era de pequeno porte. Nogueira (2005, p.166) mencionou que, na região em que estudou, eram os políticos que preenchiam as lacunas deixadas pelo comércio, acrescentando que, como empresas, as rádios precisam sustentar-se. Assim, os apoiadores culturais da rádio Largo das Flores, que pagavam em troca da execução de chamadas de divulgação de seus empreendimentos durante a programação, eram, na maioria, órgãos governamentais e empresas privadas.

0 fato de a prefeitura (e mesmo o governo estadual e federal) apoiar financeiramente essa iniciativa acabava por impedir, muitas vezes, que surgisse um episódio no qual a rádio criticasse o poder constituído de alguma forma, visto que era um recurso sem o qual a rádio não poderia se manter funcionando, levando-se em conta a falta de apoio do comércio local e toda a dificuldade em conseguir apoiadores. Assim, o poder crítico que vigora no modelo ideal de rádio comunitária se esvai em decorrência do modo de preservação ou manutenção

${ }^{13} 0$ CREA é o Conselho Regional de Engenharia e Arquitetura do Rio de Janeiro. 
da rádio comunitária. Nogueira (2005) é um dos autores que demonstrou, com seu estudo sobre as rádios em Ilhéus, esse lugar-comum em torno do silêncio desencadeado em troca da ajuda do poder municipal na manutenção das rádios: "Embora sejam mais raras pela fragilidade da relação comercial, obedecem à mesma lógica de bater para levar alguma vantagem. Ou diferentemente deixar de criticar para manter o anúncio." (NOGUEIRA, 2005, p.185). Desse modo, mesmo Marcos sendo militante orgânico do PT e possuindo, inclusive, um emprego na prefeitura (também petista), esses patrocínios competiam para diminuir ou extinguir a liberdade de criticar o governo quando fosse necessário, com debates ou a partir de programas informativos, diminuindo o leque de possibilidades de ação. Assim, para efeito demonstrativo, cito o que disse Marcos na ocasião do meu primeiro contato com ele:

Tô num trabalho de Robin Hood: tirar de quem tem e trazer pra quem precisa. Se você chegar e disser não quero, então você vai continuar sem, vai continuar não tendo. Por que eu vou bater no governo? (...) ele está me dando subsídio boje, a gente vai tentar trazer o jovem pra cá, sempre dando uma politizada em torno da cidadania, trabalhar a questão de sexualidade, a questão de preservar, a questão da doença, todo nosso curso tem isso, você não trocar o seu voto, você ver a história. (...) Vou bater no governo Federal hoje num posso ${ }^{14}$ por mais que eu sei que seja tudo aquilo que eu não quero, eu já desconfiava disso." (gravação de 15/07/2005; grifos meus)

Para ter maior independência em relação à prefeitura, seria necessário não depender tanto de suas ajudas, podendo ser intermediador da população em relação aos outros canais, como as empresas privadas que prestam serviços públicos. Portanto, a fim de não se submeter ou ser cooptado pela prefeitura, era necessário também construir sua "força política", ou seja, possuir maior número de clientes a fim de negociar com a prefeitura sob condições de maior equilíbrio. Isso compunha uma linha tênue na aceitação de certos apoios comprometedores da prefeitura. Para preservar o aparato institucional que formou, Marcos contrabalança sua perspectiva de oposição ao poder estabelecido municipal e de apoio, o que reafirma a declaração de Bourdieu (1989) sobre o trabalho de preservação institucional.

Por causa das dificuldades financeiras, Marcos pretendia fazer com que a

\footnotetext{
${ }^{14}$ No ano de 2004, a associação conseguiu aprovação para receber uma verba do governo federal mediante o Programa Cultura Viva, que financiaria o projeto de oficinas de rádio para os jovens do local, e pretendia incorporar outros meios de comunicação.
} 
associação incorporasse, cada vez mais, um perfil de ONG, captando recursos por meio de projetos. Marcos mencionou:

Quem é pobre mais pobre pode ficar (...) Se eu não tenho, vamos nos estruturar, vamos nos organizar, vamos ter uma estrutura que a gente não dependa mais dos governos. Nós temos que ser ONG, hoje qualquer doação que você faça é deduzido do imposto de renda. Na minha cabeça eu tenho todo planejamento, eu vou fazendo isso, isso, isso... Mas as ONGs que não são sérias, queimam a gente. (gravação de 15/07/2005)

Uma faixa na entrada da associação exibia o slogan: "RF FM, a sua, a nossa, rádio comunitária", e no rodapé da faixa seguia: "Associação do Largo das Flores, um projeto social". E, assim, nos demais materiais de divulgação, via-se constantemente a ostentação da expressão "um projeto social". No folder, sob o título "A Associação LF faz", encontramos alguns exemplos de projetos ou iniciativas desenvolvidas desde a implantação da associação, como por exemplo: curso de controle domiciliar do mosquito da dengue e da febre amarela em parceria com a Fundação Municipal de Saúde e a Vigilância Sanitária; disponibilização de uma hora na programação da rádio para esclarecimentos durante a semana que antecedeu o dia 'D' contra a dengue; veiculação da chamada institucional do Ministério do Meio Ambiente sobre Programa de Despoluição; confecção de panfletos e cartilhas em parceria com uma ONG sobre a questão da despoluição das águas. Além disso, eram informados projetos almejados e o encaminhamento à prefeitura de cerca de 50 ofícios relacionados à esperada resolução de problemas locais. Em acréscimo, as divisórias que segmentavam os ambientes do espaço físico da associação foram cedidas por um órgão da prefeitura, assim como as estantes de livros, mesas e um bebedouro. Verifica-se a aproximação da associação em relação aos órgãos governamentais (BOSHI,1987), procurando extrair benefícios para o local mediante tal aproximação e, ao mesmo tempo, notabilizar-se como canal capaz de encaminhar, e quiçáa resolver, por meio disso, problemas locais que legitimariam o poder da instituição.

0 reconhecimento era buscado por meio da divulgação dos atendimentos aos interesses comunitários e de parcerias com poderes mais legitimados por serem estabelecidos (ELIAS, 2000) e, assim, licenças e comprovantes de legalização da rádio e da instituição eram divulgados constantemente.

Nas redondezas da associação existem outros projetos sociais. Dois desses projetos são comandados por políticos, porém um, o Centro de Reabilitação, não 
se remete a um político local, sendo apenas uma filial que tem sua matriz fora do bairro. Assim, era com o político mais proeminente do Largo das Flores, eleito cinco vezes vereador, nitidamente de raízes locais, chamado Ernesto, que Marcos alimentava rusgas e disputas. Não entrarei no mérito das disputas políticas locais, pois não representa o foco deste artigo, cabendo bem a um outro trabalho de análise. Porém, a rádio servia como um meio do político estudado, na posição de preterido pelo governo municipal, construir sua "força política" e, assim, estabelecer um possível equilíbrio de forças no local.

A associação, em sua ânsia por prestar serviços comunitários, contava com uma biblioteca comunitária, uma escola de dança a preços populares para a qual Marcos alugava o espaço físico, uma oficina de rádio para locutores que quisessem integrar a programação e contava também com a implementação de um programa do governo federal intitulado Cultura Viva. De acordo com Auyero (2005, p.117), os programas governamentais alavancam as carreiras dos mediadores políticos e, conforme minha observação, tal programa de fato aumentou a esfera de ação do político estudado na comunidade, fornecendo-o maior visibilidade.

Certo dia, Marcos me levou à sua sala para mostrar um mapa da região que ficava colado na parede. A partir do mapa, ele me apontava os locais nos quais se situavam outras rádios, dizendo que, pela lei, as rádios deveriam se manter distantes por um raio de $1 \mathrm{~km}$. Com isso, me demonstrava o sentido de sua resposta a uma pergunta minha. Eu havia perguntado a ele se conhecia uma senhora que sempre se candidatava a vereadora e morava em um outro bairro deste município. Fiz tal pergunta por saber que ela gostaria de montar uma rádio e, de fato, havia montado uma temporariamente. Ele disse em cheio: "não vai conseguir, não vai conseguir", acrescentado "a não ser que mudem a lei”. Essa demonstração traz à cena mais um elemento concorrencial.

A necessidade de visibilidade, mantida pelos políticos, torna-se mais agressiva quando pautada pela concorrência eleitoral, que sempre vigora. Nessa concorrência, o aspecto simbólico ou de representação ocupa grande espaço na luta, pois seu poder está em proporção ao reconhecimento que recebem do grupo (BOURDIEU, 1989, p.145).

Finalmente, notamos que na rádio comunitária não podemos separar o que serve ao "público" e o que serve ao "privado". A rádio RF apareceu como um instrumento nas disputas políticas locais e também é instrumentalizada pela população em outro âmbito (não político ou por número de votos), sob linhas 
tênues de participação. Apesar de pouco relatar as atitudes dos utilizadores do espaço da associação, cabe dizer que elas serviam para a intenção de melhorar as condições do bairro (esfera pública), ao mesmo tempo em que aplacava a curiosidade de alguns participantes. Tais participantes eram essencialmente: 50 jovens Agentes Cultura Viva, comunicadores da rádio e ouvintes.

\section{Considerações Finais}

A rádio comunitária constitui a Associação do Largo das Flores, representada por Marcos. Este, muitas vezes, esforçava-se no sentido de adequar as ações da rádio ao ideal de rádio comunitária, cujos parâmetros são reforçados em lei, muito embora esse ideal fosse desconhecido e, por isso, não almejado pelos participantes do projeto. Esses caminhos utópicos que regem o ideal de rádio comunitária não poderiam ser impostos aos participantes; que mesmo não se adequando a esses modelos tinham direito ao acesso a rádio, em princípio, por pertencerem à comunidade e aceitarem certos critérios de conduta que regiam a instituição. Um desses princípios, por exemplo, era a proibição de veicular músicas com ritmo "funk".

Os comunicadores veiculavam as músicas que estavam acostumados a ouvir e, por isso, gostavam. Eram as mesmas músicas que tocavam nas rádios comerciais e que os ouvintes também requisitavam, dando a rádio preferência ao pedido da maioria. Para muitos autores, a rádio não seria considerada comunitária em sua programação, por se afinar a estilos musicais que não compõem uma alternativa à programação das rádios comerciais. Porém, a rádio pesquisada se adequava a um outro princípio julgado ideal, que era o maior acesso à participação dos indivíduos locais, que empreendiam a tarefa de comunicadores amadores. As tarefas de encaixe aos modelos ideais se revelam cheias de dificuldades.

Marcos tentava fazer da associação um canal para encaminhar e resolver problemas locais, onde os interesses privado e público confluíam. Nesse sentido, divulgações demonstrando a capacidade de resolver problemas caminhavam para fornecer projeção à instituição, que com isso esperava ganhar maior poder para efetuar mais realizações em negociação com canais responsáveis por serviços de melhoria pública. Estar em dia com a lei podia render boa fama à instituição, além de possibilitar o reconhecimento para execução de tarefas em parceria com órgãos públicos. 0 reconhecimento pelo trabalho era buscado na medida em que 
"abria portas" à entidade e, conseqüentemente, isso resvalava ou confluía com os interesses pessoais de Marcos, que, por sua vez, confundiam-se com o interesse maior da instituição - que era desenvolver a comunidade.

Marcos mencionou-me que colocar o seu rosto a fim de representar a rádio era uma estratégia para conseguir recursos para o próprio veículo, pois, sendo ele conhecido como uma pessoa séria, isso permitia uma associação benéfica para a rádio. Ou seja, ao alimentar a fama da instituição, inevitavelmente, alimentava a sua própria fama. Além disso, confidenciou-me também que recebeu cobranças e reclamações por parte da família de um dos diretores por tal diretor não aparecer em entrevistas nem ter sua figura em evidencia de alguma outra forma. Isso demonstra que esse reconhecimento consistia no objetivo de muitas pessoas, podendo ser engendrado tanto por políticos quanto por meros integrantes de movimentos sociais.

A continuidade do trabalho comunitário de Marcos depende da legitimação dos moradores. Eépreciso considerar, como mencionou Bourdieu (1989, p.143,145, 151), que a passagem do desconhecido ao reconhecido demanda um trabalho árduo e constante, que depende da modificação de posições sociais num espaço. A partir do momento em que outros projetos sociais são desenvolvidos na área, principalmente por políticos, pode-se prever uma concorrência pela preferência da clientela.

0 aspecto discursivo, valorizado pelos políticos e representantes de movimentos sociais, encontra na rádio comunitária um canal de realização. Esse traço de manejo simbólico ou de representação dialoga com posições sociais concretas, entrando no jogo da concorrência política e fornecendo prestígio e reconhecimento aos diversos atores. E, aqui, rompe-se com uma literatura sobre rádio comunitária que percebe a dinâmica social como um jogo de oposições, entre os "bons" dominados e os "perversos" dominantes. Ou os "justos" e "salvadores" movimentos sociais e os "desonestos" e "corruptos" políticos.

\section{REFERÊNCIAS}

AUYERO, Javier. La Política de Los Pobres. Buenos Aires: Manatial, 2005.

ALEXANDER, Jeffrey C. Ação Coletiva, Cultura e Sociedade Civil: secularização, atualização, inversão, revisão e deslocamento do modelo clássico dos movimentos 
sociais. Revista Brasileira de Ciências Sociais, vol. 13, nº 37, São Paulo, jun/1998, p. 5-31.

BIANCO, Nélia Rodrigues Del. Rádio Populista. Dissertação (Mestrado em Sociologia) - Departamento de Ciências Sociais, Universidade de Brasília: Brasília, 1991. $259 \mathrm{f}$.

BOSHI, Renato. "Movimentos sociais e democratização: Questões teóricas". In: $A$ Arte da Associação. Rio de Janeiro: Vértice, 1987, p. 23-39.

BOURDIEU, Pierre. "O Espaço Social e a Gênese das Classes"; "Introdução a uma Sociologia Reflexiva" e "A Identidade e a Representação: elementos para uma reflexão critica sobre a idéia de região". In: O Poder Simbólico. Lisboa/Rio de janeiro: Difel/ Bertrand Brasil, 1989, p. 17-58, 133-161, 107-132.

COSTA, Carlos Eduardo Machado da. "Conclusão". Do microfone ao Plenário: o comunicador radiofônico e seu sucesso eleitoral. Dissertação (Mestrado em Comunicação) - Faculdade de Comunicação, Universidade de Brasília: Brasília, 1997.

COSTAJÚNIOR, Achylles de Oliveira. Da Clandestinidade à Legalidade: 0 discurso social sobre as rádios comunitárias. Dissertação (Mestrado em Comunicação) - Departamento de Comunicação Social, Universidade Federal do Rio de Janeiro: Rio de Janeiro, 1999.

DOUGLAS, Mary. Pureza e Perigo. São Paulo: Perspectivas, 1966.

ELIAS, Norbert. Os Estabelecidos e os Outsiders: sociologia das relações de poder a partir de uma pequena comunidade. Rio de Janeiro: Jorge Zahar, 2000

GUIDDENS, Anthony. As Conseqüências da Modernidade. São Paulo: UNESP, 1991.

HOBSBAWN, Eric. Rebeldes Primitivos: estudo sobre as formas arcaicas dos movimentos sociais nos séculos XIX e XX. Rio de Janeiro: Zahar Editores, 1970.

HONNETH, Axel. Luta por Reconhecimento. São Paulo: Editora 34, 2003.

IANNI, Octávio (org). "Introdução". In: Marx. $3^{a}$ ed. São Paulo: Ática, 1982. (Coleção Grandes Cientistas Sociais).

LUZ, Dioclécio. Rádios Comunitárias: trilha apaixonada e bem humorada do que é e de como fazer Rádios Comunitárias na intenção de mudar o mundo. Brasília: s./n, 2001. 
MARX, Karl; ENGELS, Friedrich. A Ideologia Alemã. São Paulo: Martins Fontes, 2002.

MELLO, Veridiana Pivetta de. Rádio: um meio estruturador do local. Dissertação (Mestrado em Comunicação) - Escola de Comunicação Social, Universidade Federal do Rio de Janeiro: Rio de Janeiro, 1999. 90 f.

MERTON, Robert K. A Profecia que se Cumpre por si Mesma. In: Sociologia: Teoria e Estrutura. São Paulo: Editora Mestre Jou, 1970, p. 515 a 552.

MIGUEL, Luís Felipe. Capital Político e Carreira Eleitoral: algumas variáveis na eleição para o congresso brasileiro. Revista de Sociologia e Política, n 20 , Curitiba, jun/2003. Disponível em www.scielo.com.br, acessado em setembro de 2005. 